\title{
Low Load Prolonged Stretch vs. High Load Brief Stretch in Treatment of Knee Contracture after Burn
}

\author{
HAIDY N. ASHM, Ph.D.*; AHMAD A. MOHAMMED, Ph.D.**; KHADRA M. ALI, Ph.D.* and \\ YASSMIN M. EL-TABAKH, M.Sc.*** \\ The Department of Physical Therapy for Surgery, Faculty of Physical Therapy*, The Department of General Surgery, \\ Faculty of Medicine**, Cairo University and Physical Therapy Department, 6 th October Hospital***
}

\begin{abstract}
Background: Burn is defined as a traumatic injury to the skin or other organic tissue primarily caused by thermal or other acute exposures. Burns occur when some or all of the cells in the skin or other tissues are destroyed by heat, cold, electricity, radiation, or caustic chemicals. Burns are acute wounds caused by an isolated, non-recurring insult and progress rapidly through an orderly series of healing steps.
\end{abstract}

Aim of Study: This study was conducted to investigate effect of low load prolonged stretchvs. High load brief stretch post burn knee contracture.

Subjects and Methods: Thirty patients with knee contracture following burn were conducted in the present study. All patients with age ranged from 25 to 45 years. They were selected from Om Al-Masreen Hospital, and Kasr El-Ainy Hospital. Patients assigned randomly into two groups (A and B) equal in number: Group (A) fifteen patients received low load prolonged stretch using weights (sand bags) 3 times/ week for 4 successful weeks. Group (B) fifteen patients received manual stretch 3 times/week for 4 successful weeks.

Evaluation: Evaluations of both groups (A and B) were done before starting the treatment and at the end of study by Goniometer and Foot print to measure range of motion and cadence pre and post-treatment.

Results: This study showed a statistically significant increase of knee joint ROM with percentage of improvement $(14.4 \pm 4.89)$ in group (A), compared with group (B) with percentage of improvement $(19.4 \pm 5.15)$.

Conclusion: The present study concluded that low load prolonged stretch is more effective than high load brief stretch in treatment of knee contracture after burn.

Key Words: Low load prolonged stretch - Knee contracture - High load brief stretch - Goniometer - Foot print.

Correspondence to: Dr. Haidy N. Ashm, The Department of Physical Therapy for Surgery, Faculty of Physical Therapy, Cairo University

\section{Introduction}

BURN is defined as a traumatic injury to the skin or other organic tissue primarily caused by thermal or other acute exposures. Burns occur when some or all of the cells in the skin or other tissues are destroyed by heat, cold, electricity, radiation, or caustic chemicals. Burns are acute wounds caused by an isolated, non-recurring insult and progress rapidly through an orderly series of healing steps [1].

Post-burn scars are inevitable even with the best of treatment because they depend upon the depth of burn injury. Except for the superficial dermal burns, all deeper burns ( 2 nd degree deep dermal and full thickness) heal by scarring the deeper tissues may be affected either due to their involvement in the initial burn injury (e.g., electrical burns) or secondary to the presence of a skin contracture over a prolonged period of many years, which leads to shortening of musculotendinous units and neurovascular structures. The joints may be subluxated or dislocated, with joint capsule and ligaments becoming tight in the direction of the contracture [2]

Scar contracture is the end result of the process of contraction. Contraction is an active biological process by which an area of skin loss in an open wound is decreased due to concentric reduction in the size of the wound. The reduction in size of wound causes lesser degree of connective tissue deposition and the amount of epithelialisation needed is decreased. Wound contraction involves an interaction of fibroblasts, myofibroblasts and collagen deposition and is a satisfactory mechanism when the tissue loss is small, in a non-critical area and surrounded by loose skin [3] . 
Knee post burn scar flexion contractures, making up $22 \%$ of large joint contractures affect the leg motion, impair the lower extremity function, present cosmetic defects. The contracted scars undergo (during joint extension) severe tension, tearing, and often are converted to pathologic scarsrough, thick, solid, prone to keloid growth and ulceration [2].

Manual passive stretching is a physical treatment administered by a therapist to joints that the patient is not able to move independently [4]

The therapist manually moves the affected joint to the limit of its range of movement and holds this stretch position briefly before repeating the procedure. In the context of rehabilitation this treatment is given to maintain joint range of movement and counteract the development of contracture and to reduce muscle spasticity which may contribute to the development of contracture. Joints need regular movement to maintain their mobility. When a joint cannot be moved regularly through its full range of motion physiological changes occur in the surrounding muscles and other tissues causing them to shorten, which restricts mobility about the joint [5].

\section{Subjects and Methods}

This study was started from February 2018 till Mach 2018 at Om Al-Masreen Hospital, and Kasr El-Ainy Hospital. In Cairo, Egypt.

Subjects: Thirty patients had a lower limb burn of second degree. They are suffering from contracture of knee joint. They were selected from Om Al-Masreen Hospital, and Kasr El-Ainy Hospital and patients were assigned randomly into two groups of equal numbers, (group A and group B).

Inclusive criteria: All patients participated in this study were males and females, age ranged between 25 and 45 years, had post burn knee contracture following second degree of burn of the lower limb, and have sufficient cognition and education enough to understand the requirements of the study.

Exclusive criteria: All patients had osteoporosis, had vestibular condition, had joint replacement within the past year, diagnosed with acute rheumatoid arthritis, hadpost-operative wounds or who haddermatological infection were excluded from this study.
Equipment: The study equipment were divided into two different categories, measuring and therapeutic equipment.

Measuring equipment: Evaluation of knee range of motion using goniometer and gait analysis.

Treatment equipment: Group (A) receivedprolonged stretch, single pulley and a weight was used. The length of each LLPS treatment was one hour daily, three times per week for 4 successful weeks. Group (B) received a maximum manual stretch. Each week 3 times, each time 3 groups of 5 repetitions, for 4 successful weeks. Force was used did not cause injury.

Procedure of application: The subjects will be informed about the nature of the study; each subject signed consent form before participating in the study. Treatment time of the present study was given in the period of 4 weeks.

- Group A: Patients in study group treated withprolonged stretch by single pulley and a weight, one hour, three times per week for 4 successful weeks.

- Group B: Patients receive maximum manual stretch, 3 times weekly. Each time 3 group of 5 repetitions, for 4 successful weeks.

Ethical consideration: Confidentiality was assured by signing the consent form and respect to all patients was ascertained through explaining the objectives of the study and its benefits. The study was approved by Ethical Committee of Faculty of Physical Therapy, Cairo University. (P. T.REC/012/001000).

\section{Results}

Comparing the general characteristics of the subjects of both groups revealed that there wasno significant difference between both groups in the mean age values $(p=0.76)$.

The sex distribution of the group B revealed that there were 7 females with reported percentage of $47 \%$ while the number of males was 8 with reported percentage of $53 \%$ as shown in (Table 1).

Table (1): The frequency distribution and chi squared test for comparison of sex distribution between both groups (A and B).

\begin{tabular}{lrrrrr}
\hline & Group A & Group B & $\mathrm{X}^{2}$-value & $p$-value & Sig. \\
\hline Females & $8(53 \%)$ & $7(47 \%)$ & 0.13 & 0.71 & NS \\
Males & $7(47 \%)$ & $8(53 \%)$ & & & \\
\hline $\mathrm{X}^{2} \quad$ : Chi squared value. & & & \\
$p$-value: Probability value. & & & \\
NS $\quad$ Non Significant.
\end{tabular}


The mean \pm SD age of group A was $33.53 \pm 5.15$ years, with maximum value of 40 years and minimum value of 25 years. The mean $\pm \mathrm{SD}$ age of group B was $34.06 \pm 4.6$ years, with maximum value of 40 years and minimum value of 26 years. There was no significant difference between both groups in the mean age values $(p=0.76)$ as shown in (Table 2).

Table (2): Comparison of the mean values of age between group A and B.

\begin{tabular}{llll}
\hline & & Group A & Group B \\
\hline \multirow{2}{*}{ X \pm SD } & $33.53 \pm 5.15$ & $34.06 \pm 4.6$ \\
Minimum & 25 & 26 \\
Maximum & 40 & 40 \\
MD & \multicolumn{2}{c}{-0.53} \\
& $t$-value & \multicolumn{2}{c}{-0.29} \\
& $p$-value & \multicolumn{2}{c}{0.76} \\
& Significance & \multicolumn{2}{c}{ NS } \\
\hline X & : Mean. & \multicolumn{2}{c}{ SD : Standard Deviation. } \\
MD & : Mean Difference. & \multicolumn{2}{c}{$t$-value : Unpaired $t$-value. } \\
$p$-value : Probability value. & NS : Non Significant.
\end{tabular}

The mean \pm SD knee flexion deformity rom pre-treatment of group A was $27.53 \pm 7.01$ degrees and that post-treatment was $14.4 \pm 4.89$ degrees. The mean difference between pre and posttreatment was 13.13 degrees and the percent of change was $47.69 \%$. There was a significant decrease in the knee flexion deformity of group A post-treatment compared with pre-treatment $(p=$ 0.0001) (Table 3).

Table (3): Paired $t$-test for comparison between pre and posttreatment mean values of knee flexion deformity rom of group A.

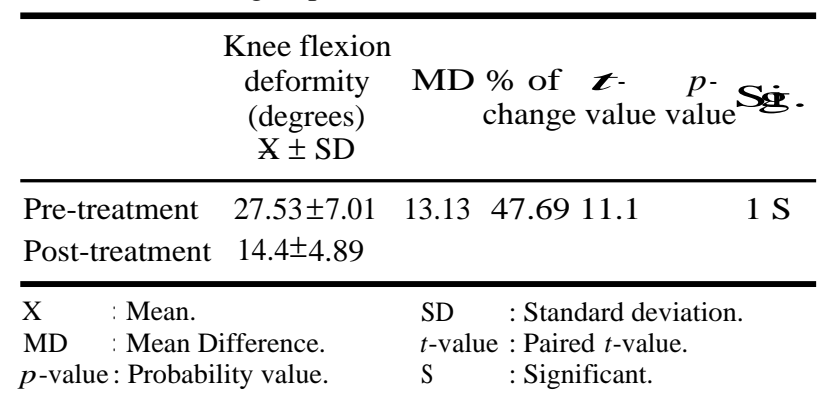

The mean \pm SD knee flexion deformity rom pre treatment of group B was $26.66 \pm 6.88$ degrees and that post-treatment was $19.46 \pm 5.15$ degrees. The mean difference between pre and posttreatment was 7.2 degrees and the percent of change was $27 \%$. There was a significant decrease in the knee flexion deformity of group B posttreatment compared with pre-treatment $(p=0.0001)$ (Table 4).
Table (4): Paired $t$-test for comparison between pre and posttreatment mean value of knee flexion deformity rom of group B.

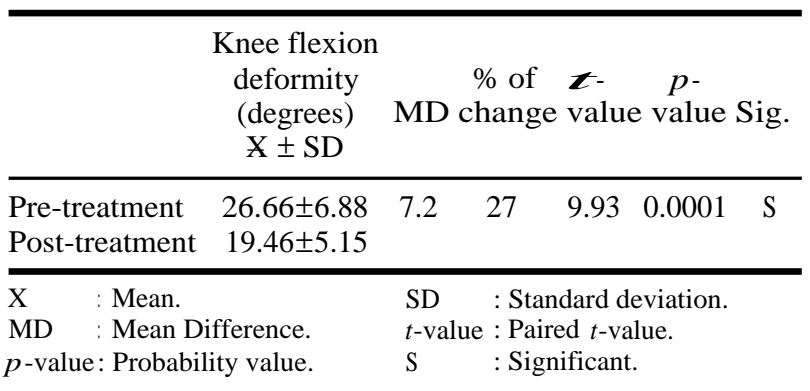

The mean \pm SD knee flexion deformity rom post-treatment of grup A was $14.4 \pm 4.89$ degrees and that of group B was $19.4 \pm 5.15$ degrees. The mean difference between both groups was -5.06 degrees. There was a significant decrease in the knee flexion deformity of group A compared with that of group B post-treatment ( $p=0.01)$ (Table 5).

Table (5): $t$-test for comparison between post-treatment mean values of knee flexion deformity of group A and B.

\begin{tabular}{|c|c|c|c|c|c|}
\hline & $\begin{array}{c}\text { Knee flexion } \\
\text { deformity } \\
\text { (degrees) } \\
\text { X } \pm \text { SD }\end{array}$ & MD & $\begin{array}{c}t- \\
\text { value }\end{array}$ & $\begin{array}{c}p- \\
\text { value }\end{array}$ & Sig. \\
\hline $\begin{array}{l}\text { Group A } \\
\text { Group B }\end{array}$ & $\begin{array}{l}14.4 \pm 4.89 \\
19.46 \pm 5.15\end{array}$ & -5.06 & -2.76 & 0.01 & S \\
\hline $\begin{array}{l}\mathrm{X} \\
\mathrm{MD}: \mathrm{N} \\
p \text {-value }: \mathrm{P}\end{array}$ & $\begin{array}{l}\text { Difference. } \\
\text { ability value. }\end{array}$ & $\begin{array}{l}\mathrm{SD} \\
t \text {-value } \\
\mathrm{S}\end{array}$ & $\begin{array}{l}\text { : Standa } \\
: \text { Paired } \\
: \text { Signifi }\end{array}$ & $\begin{array}{l}\text { rd deviation. } \\
t \text {-value. } \\
\text { cant. }\end{array}$ & \\
\hline
\end{tabular}

\section{Discussion}

The current study was designed to evaluate the therapeutic efficacy of low load prolonged stretch vs. high load brief stretch post burn knee contracture using the parameters involved Goniometer as a method of evaluation at different times:

- Pre-treatment application (before treatment).

- Post-treatment application (after 4 weeks of treatment).

Stretching exercises have been traditionally used in treating hypo mobility, based on the biological principle that connective tissue will remodel over time in response to physical stress. At the cellular level, motion restrictions involve the formation of cross bonds of the periarticular connective tissue that forms between the collagen bundles [6].

Stretchingis a general term used to describe any therapeutic maneuver designed to increasethe extensibility of soft tissues, thereby improving 
flexibility and ROM by elongating (lengthening) structures that have adaptively shortened and have become hypo-mobile over time [7]

Physical therapy may include manual stretching; prolonged stretching using a tilt table, prolonged stretching using a sandbag/weight over the distal femur, mechanical traction, passive range of motion exercises and joint mobilization. The effectiveness of a given treatment to reduce flexion contractures is a function of the applied torque, as well as the duration and frequency of the treatment [8]

Passive stretching is a common treatment to combat this soft tissue tightness. The stretching can be done manually by the therapist or the patient or by other external devices such as splints, casts, or tilt-table. 5 despite the widespread use of passive stretching; there is a lack of research evidence demonstrating its effectiveness and the rationale behind the stretch-based techniques in spastic human muscles [9].

Low-intensity stretching (coupled with a longduration of stretch) results in optimal rates of improvement in ROM without exposing tissues, possibly weakened by immobilization to excessive loads and potential injury [10].

IN passive stretching, once the end range was achieved, this position was manually maintained for one minute followed by a 15 -second rest. Patient received 3 times/week and each time consisted of 3 groups, each group consisted of 5 repetitions [11].

Bags filled with sand were used as weights. The sand bags applied traction force that allowed the ROM to increase, one hour, 3 times weekly for 4 weeks [12].

This concept was supported by some previous studies and past literatures that conducted by following authors: $[\mathbf{5 , 8 , 1 2}]$.

- The therapist manually moves the affected joint to the limit of its range of movement and holds this stretch position briefly before repeating the procedure. In the context of rehabilitation this treatment is given to maintain joint range of movement and counteract the development of contracture and to reduce muscle spasticity which may contribute to the development of contracture. Joints need regular movement to maintain their mobility. When a joint cannot be moved regularly through its full range of motion physiological changes occur in the surrounding muscles and other tissues causing them to shorten, which restricts mobility about the joint.
- Manual stretching, prolonged stretching using a tilt table, prolonged stretching using a sandbag/ weight over the distal femur, mechanical traction, passive range of motion exercises and joint mobilization. The effectiveness of a given treatment to reduce flexion contractures is a function of the applied torque, as well as the duration and frequency of the treatment.

- Mechanical stretching devices apply a very lowintensity stretch force (low-load) over a prolonged period of time to create relatively permanent lengthening of soft tissues, presumably due to plastic deformation.

\section{Conclusion:}

From the previous results and discussions, it could be concluded that, low load prolonged stretch improves knee ROM of patient suffer from contracture post burn more than manual passive stretch.

\section{References}

1- HOLLAND A.J., MARTIN H.C. and CASS D.T.: Laser Doppler imaging prediction of burn wound outcome in children. Burns, 28: 11-7, 2002.

2- SCHNEIDER J.C., HOLAVANAHALLI R., HELM P., GOLDSTEIN R. and KOWALSKE K.: Contractures in burn injury: Defining the problem". J. Burn Care Res., 27: 508-14, 2006

3- FOX P., RICHARDSON J. and McINNES B.: Effectiveness of a bed positioning program for treating older adults with knee contractures who are institutionalized. Phy. Ther., 80: 363-72, 2000.

4- De DEYNE P.G.: "Application of passive stretch and its implications for muscle fibres". Phys. Ther., 81: 819-27, 2001.

5- FARMER S.E. and JAMES M.: Contractures in orthopaedic and neurological conditions: A review of causes and treatment. Disabil. Rehabilitation, 23: 549-58, 2001.

6- CUMMINGS G. and TILLMAN L.: Remodeling of dense connective tissue in normal adult tissues. In: Currier D, Nelson R, ed. Dynamics of Human Biologic Tissues. Philadelphia, PA: FA Davis Co.; 45-73, 1999.

7- PENNICK V.E. and YOUNG G.: Interventions for preventing and treating pelvic and back pain in pregnancy. Cochrane Database Syst. Rev., 18 (2): CD001139, 2007.

8- TIMOTHY L.: Torque Measures of Common Therapies for the Treatment of Flexion Contractures, 26: 328-34, 2010.

9- GRACIES J.M.: Pathophysiology of impairment in patients with spasticity and use of stretch as a treatment of spastic hypertonia. Phys. Med. Rehabil. Clin. N. Am., 12: 74768, 2001.

10- MacKAY-LYONS M.: Low-load prolonged stretch in treatment of elbow flexion contractures secondary to head trauma: A case report. Phys. Ther., 69 (4): 292-6, 1989.

11-CAROLYN KISNER and LYNN ALLEN COLBY.: "Therapeutic Exercise: Foundations and Techniques, 2012. 
12- BLANTON S., GRISSOM S.P. and RIOLO L.: Use of a static adjustable ankle-foot orthosis following tibial nerve block to reduce plantar-flexion contracture in an individual with brain injury. Phys. Ther., 82 (11): 1087-97, 2002.

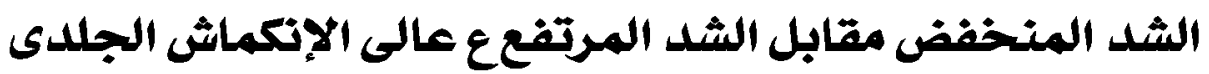

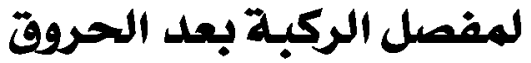

آجريت هذه الدراسة لمعرفة تآثير الشد المنذفض مقابل الشد المرتفع على الإنكماش الجلدى على المرضى الذين يعانون تخشب مفصل الركبة عقب الحرق.

مواد وآساليب العلاج: لقد شارك فى هذه الرسالة ثلاثن مريض ومريضة ممن يعانون تخشب مفصل الركبة عقب الحروق وقد تم إختيارهم

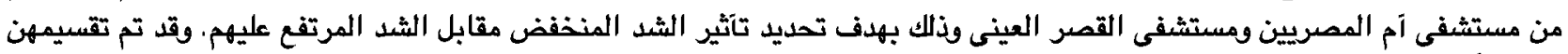

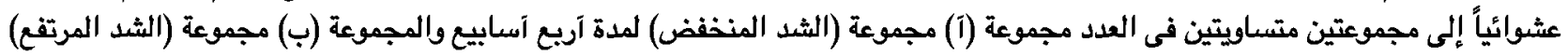

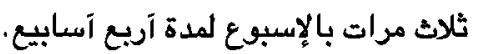

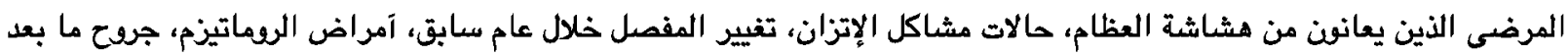

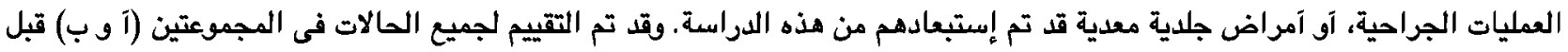
بداية الدراسة وبعد مرود آريع آسابيع ومن خلال فحص مدى الحركة إيعا ستخدام الجونيوميتر وتحليل سرعة المشى.

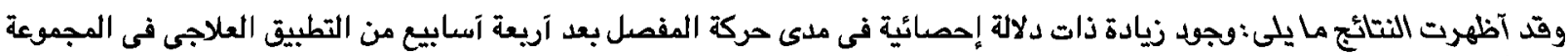

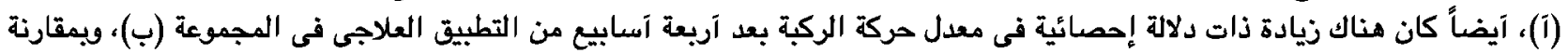

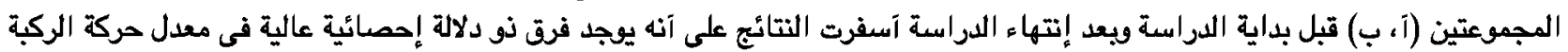

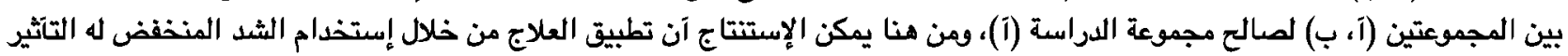

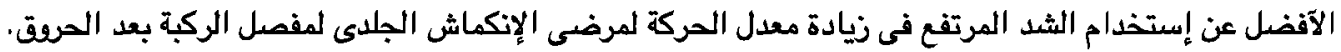
ولقد إشتملت هذه الدراسة على إثنى عشر (rir ) مرجعاً تم ترتيهم ترتيب آبجدياً. 